\title{
PEMIKIRAN PEMBARUAN TEOLOGI ISLAM SYAH WALI ALLAH AD-DAHLAWI
}

\author{
H. Ghazali Munir \\ IAIN Walisongo Semarang \\ ghozalimunir@yahoo.com
}

\begin{abstract}
Pemikiran pembaruan teologi Islam Syah Wali Allah adDahlawi tidak hanya berfokus terhadap ajaran Islam tertentu belaka, tetapi bersifat komprehensif. Baik terhadap aspek politik, pemahaman terhadap ajaran Islam, dan lainnya. Serta menyeru untuk kembali kepada alQur'an dan as-Sunnah, dan mayoritas sahabat dan tabi'in. Aspek politik, ia mengajak kembali pada sistem khulafa'urrasyidin, mendamaikan perbedaan paham yang ada pada mazhab, membersihkan kepercayaan dari non Islam, ijtihad disesuaikan dengan tuntutan zaman.
\end{abstract}

Kata kunci: Iman, amal, munafiq, kufur, tasdiq, fasiq, khalqu.

\section{PENDAHULUAN}

Tulisan ini akan menyoroti pemikiran teologi Syah Wali Allah adDahlawi. Yang akan dijadikan sebagai rujukan utama kajian ini adalah karya monumental ad-Dahlawi yang berjudul $H_{j}$ ujjah Allah al-Baligah. Ada beberapa alasan kitab tersebut dijadikan sebagai bahan utama mengungkap pemikiran teologi ad-Dahlawi, meskipun kitab itu bukan semata-mata sebuah karya bidang teologi. Pertama, kitab Hujjah Allah alBaligah adalah kitab yang komprehensif yang meliputi segala kajian pemikiran Islam, bahkan W.C. Smith menyebutnya sebagai karya terbesar ad-Dahlawi $>{ }^{1}$ Sebagai karya terbesar, tidak mengherankan kalau kitab ini telah lama dijadikan sebagai textbook standar di Universitas al-Azhar Kairo, ${ }^{2}$ dan banyak diterjemahkan ke berbagai bahasa. ${ }^{3}$ G.N. Jalbani menilainya sebagai sebuah ensiklopedi ilmu-ilmu keagamaan. ${ }^{4}$ Sayyid $\mathrm{Sa}>$ biq secara lebih khusus mengatakan bahwa kitab tersebut secara tidak langsung menjadi saksi bahwa penulisnya sesungguhnya merupakan salah seorang pioneer pemikiran Islam dan ilmu-ilmu aqliyah. ${ }^{5}$ Kedua, sebagai 
karya terbesar, bahkan kadang-kadang menjadi sebutan nama Syah Wali Allah sendiri, ${ }^{6}$ jarang sekali dikaji dari aspek teologinya, karena biasanya hanya dikenal sebagai kitab yang membahas Filsafat Hukum Islam atau rahasia-rahasia syariah. Tentunya hal ini berakibat kurang adil dalam memandang kitab tersebut dalam kedudukannya sebagai kitab yang memuat pembaharuan-pembaharuan di berbagai bidang kajian Islam. Ketiga, sebagai seorang pembaharu yang total, sulit dicari karya ad-Dahlawiyang khusus memuat kajian tertentu, sekalipun ada beberapa kitabnya yang diberi judul secara khusus atau memuat kajian secara khusus, seperti di bidang tafsir dan hadis, tetapi di bidang pemikiran yang sifatnya mempunyai keterkaitan dengan ide-ide pembaharuannya yang lain, seperti di bidang teologi, sulit ditemukan. Untuk memperdalam pemikiran teologi ad-Dahlawi>, penulis merujuk kitab-kitabnya yang lain, sehingga dapat menampilkan pemikiran teologi Syah Wali Allah yang sebenarnya.

\section{RIWAYAT HIDUP}

Nama lengkap Syah Wali Allah ad-Dahlawi adalah Qut $\}$ b ad-Din Ah\}mad ibn asy-Syah 'Abd ar-Rah\}im ibn Wajih ad-Din asy-Syahid ibn Muqaddam ibn Mansur ibn Ah\}mad ibn Mahmud ibn Qiwam ad-Din. Ia mempunyai silsilah sampai kepada salah seorang sahabat dan khalifah terkemuka, Umar ibn al-Khat $\} \mathrm{t}\} \mathrm{a}>\mathrm{b}$ al-Faruq. ${ }^{7}$ Oleh karena itu sebagian penulis menambah namanya dengan al-Umari al-Faruqi.

Ad-Dahlawi lahir pada tanggal 4 Syawal 1114 H/1703 M di Delhi dan meninggal pada tahun $1176 \mathrm{H} / 1762 \mathrm{M}$. Ayahnya adalah seorang sufi dan ulama besar pada zamannya yang mempunyai madrasah, yang dikemudian hari diberi nama Madrasah Rahimiyah oleh ad-Dahlawi. Syah Abd ar-Rahim adalah seorang murid terkemuka dari seorang ulama besar, Mirza Muhammad Zahid al-Harawi (w. 1111 H). Kebesaran ayahnya itu dibuktikan dengan dimasukkannya sebagai team penyusun Fatawa 'Alamgiri atau yang dikenal dengan Fatawa Hindiyah, sebuah kodifikasi fiqh (Mazhab Hanafi) yang dibuat atas perintah Raja Aurangzeb Bahadur Alamgir (w. $1118 \mathrm{H}){ }^{8}$

Dilihat dari segi namanya yang menggunakan gelar Syah menunjukkan ia dari keluarga terhormat. Gelar Wali Allah dan Qutb ad-Din, menurut ceritera yang dapat dipercaya, diberikan oleh ayahnya, Syah Abd ar-Rahim, setelah sebelumnya sering bermimpi bahwa ia akan diberi putera yang saleh bahkan pemberitahuan itu tidak hanya didapatkan melalui mimpi, tetapi juga datang seorang yang bernama Qut $\} \mathrm{b}$ ad-Di $>n$ Bakhtiyar 
Ka'ki yang dianggap sebagai seorang wali yang paling menonjol. Selanjutnya Bakhtiyar Ka'ki meminta kepada Syah Abd ar-Rahim, agar anaknya nanti diberi nama Wali. Setelah anaknya lahir, permintaan tersebut dipenuhi dengan memberi nama pada anaknya Qut $\} b$ ad-Din yang kemudian setelah dewasa terkenal dengan Wali Allah. ${ }^{9}$

Dengan dibekali ilmu yang diberikan oleh ayahnya, ad-Dahlawi tumbuh sebagai seorang yang mampu mengajari semua aspek ajaran Islam. Umur 5 tahun ia sudah menekuni ilmu di Madrasah milik ayahnya dan umur 7 tahun ia telah hafal al-Qur'an seluruhnya. Pada tahun $1731 \mathrm{M}$, ia pergi ke Hijaz untuk memperdalam ilmu-ilmu keagamaan seperti hadis, fiqh dan tasawuf. Untuk ilmu yang terakhir itu ia telah mendapatkan 'ijazah' dari seorang gurunya yang bernama Syaikh Abu Tahir al-Madaniseorang ulama sufi terkenal. Mengenai perjalanannya ke Hijaz tersebut, menurut $M$. Mujeeb karena ingin menghindarkan diri dari ancaman ulama-ulama tradisional India, karena ad-Dahlawi telah memberanikan diri menterjemahkan al-Qur'an ke dalam bahasa Persia, suatu usaha yang dianggap masih tabu pada saat itu. ${ }^{10}$ Namun pendapat ini banyak yang menentangnya, karena Syah Wali Allah sendiri tidak bercerita, sebagaimana ia banyak menceritakan pengalamannya melalui beberapa kitabnya. Ada satu hal menarik dari perjalanan ad-Dahlawitersebut, menurut penuturannya dalam kitab Fuyu' al-H\{ara>main dan at-Tafhimat, ia telah bertemu dengan ruh Nabi Muhammad saw. dan memperoleh ma'rifah, ilmu dan bimbingan serta berbagai keistimewaan dari Nabi. Dengan pengalamannya ini ia menggunakan gelar Uwaisy dan Wasi, bahkan menyebutnya sebagai mujaddid. Ceritera yang hampir sama juga dituturkan dalam kitabnya $H\{u j j a h$ Alla $>$ al-Ba>ligah bahwa suatu ketika ia bermimpi bertemu dengan al-Hasan dan al-Husain, keduanya seakan memberi sebuah pena (qalam) seraya mengatakan bahwa pena itu mereka dapatkan dari Rasulullah saw. ${ }^{11}$

Tahun $1145 \mathrm{H}$, ad-Dahlawikembali ke India, tepatnya setelah selama 14 bulan berada di Hijaz. Dengan kekuatan ilmu dan keyakinannya bahkan dengan pengalaman-pengalaman spiritual yang ia dapatkan sewaktu berada di Makkah, ia mulai bertambah gencar melakukan gerakan-gerakan pembaharuan di India. Ia meneruskan pekerjaannya yang lama sebagai guru dan banyak mengarang buku. ${ }^{12} \mathrm{Di}$ antara karya-karya terpenting Syah Wali Allah ad-Dahlawi adalah: $H\{$ ujjah Allah al-Ba $>$ ligah, al-Fawz al-Kabi $>r$ fi $\left.>U_{s\}}\right\}>l$ at-Tafsi $>r$, al-Insa $>f f i>$ Baya $>n$ as-Asba $>b$ al-Ikhtila $>f$, Iqd al-Jid fi>Ah\}kam al-Ijtiha $>d$ wa at-Taqli $>d$, Syarh\} Tara $>$ jim Abwa $>b$ 
S\}ah\}i>h al-Bukha>ri>, at-Tafhimat al-Ila>hiyyat, al-Fuyu $>d$ al$H\{$ ara $>$ main wa Anfasi al-'A<rifi $>n$, al-Juz al-Lat $\}>f$ fi $>$ Tarjamah Abd $a d\}-D\} a>$ 'if, Izalat al-Khafa an Khila $>$ fah al-Khula $>f a>$, al-Irsya $>d f i>$ Muhimmah al-Isna $>$ d, al-Buzlur al-Ba>zigah, al-Khair al-Kasli>r, dan lain-lain.

Mengenai karya-karya ad-Dahlawi ini terdapat perbedaan pandangan. Zafr al-Islam Khan, menyatakan bahwa karya tulis ad-Dahlawi lebih dari seratus kitab. Abd al-Mun'im an-Namir menyebutnya sekitar lima puluh empat kitab yang tertulis dalam bahasa Arab dan Persia. ${ }^{13}$ Bahkan menurut al-Kandahlawi, sulit menghitung karya-karya ad-Dahlawi yang tersebar di berbagai bidang ilmu dan pengetahuan. ${ }^{14}$ Kesulitan untuk menentukan berapa jumlah karya Syah Wali Allah ad-Dahlawi tersebut dapat dimaklumi, karena disamping banyaknya karya yang telah diciptakan, juga terdapat beberapa karya yang kajiannya hampir sama antara kitab yang satu dengan yang lain. Contohnya, kajian mengenai Asbab al-Ikhtilaf wa al-Tabi' in fi alFuru' dalam kitabnya Hujjah Allah al-Baligah, hampir sama dengan kajiannya yang termuat dalam kitabnya al-Insaffi Bayan al-Asbab al-Ikhtilaf.

Penulis tidak perlu terlalu jauh mengkaji masalah ini, karena disamping akan keluar dari pokok kajian dalam penulisan ini, untuk mengkaji karya Syah Wali Allah ad-Dahlawi tidak bisa dilakukan dengan cara yang sederhana, terlebih lagi kalau akan membandingkan karya yang satu dengan karya yang lain, karena karya-karya ad-Dahlawi sangat komprehensif dan komplek. Bahkan para penulis berikutnya, yang secara khusus melakukan kajian terhadap karya-karya ad-Dahlawi pun merasa kesulitan, seperti yang tertuang dalam tulisan Mas'ud an-Nadawi dalam bukunya Tarikh al-Da'wah al-Islamiyah fi Hind, A.J. Helepota dalam bukunya Philosophy of Shah Wali Allah, S.A. Abbas Rizvi dalam Shah Wali Allah and His Time.

Kesulitan-kesulitan yang dimaksudkan adalah munculnya karyakarya yang rasionalistik dan sufistik dari ad-Dahlawi. Salah satu contohnya, dalam karya Hujjah Allah al-Baligah, pada bagian pendahuluan ia menerangkan pengalaman sufistiknya bermimpi bertemu dengan dua orang cucu Nabi yaitu al-Hasan dan al-Husain, tetapi pada bagian-bagian isinya ia banyak menggunakan teori-teorinya yang sangat rasional yang secara tidak langsung menunjukkan intelektualitasnya yang tinggi, seperti teori sosiologisnya mengenai empat tahap evolusi sosial, yaitu:

1. Al-Irtifaq al-Awwal, tahap ini manusia hanya bergerak untuk memenuhi kebutuhan semata. 
2. Al-Irtifaq al-Sani, tahap kedua ini manusia membutuhkan orangorang yang dapat membimbingnya, karena problem manusia sudah bertambah.

3. Al-Irtifaq al-Salis, pada tahap ini manusia perlu mengangkat seorang raja (pemimpin) guna menyelesaikan persengketaan yang pasti terjadi diantara mereka.

4. Al-Irtifaq al-Rabi', pada tahap keempat ini manusia membutuhkan seorang khalifah (Nabi) yang dapat mengatasi berbagai pertikaian antara raja-raja yang muncul pada tahap ketiga. Khalifah yang dimaksudkan adalah seorang pemimpin yang dapat mengatasi semua raja-raja yang ada. ${ }^{15}$

Barangkali kutipan yang dikemukakan oleh S.A.A. Rizvi dari buku Tafhimat al-Ilahiyat, karangan ad-Dahlawi sendiri, dapat dijadikan pegangan untuk menilai metode berpikirnya ad-Dahlawi. Dalam kutipan tersebut dijelaskan bahwa metode berfikir ad-Dahlawi didasarkan pada burhan (demonstrative proof), wijdan (intuition), dan manqul (traditional knowledge). ${ }^{16}$

Dengan memperhatikan sedikit uraian di atas, muncul suatu pertanyaan, yaitu corak pembaharuan yang bagaimanakah yang dilakukan oleh ad-Dahlawi? Pertanyaan ini muncul, karena sebagaimana telah diterangkan di atas bahwa ad-Dahlawi adalah salah seorang sosok pembaharu yang paling banyak mempengaruhi pembaharuan-pembaharuan di India pada masa-masa sesudahnya. Namun, pertanyaan itu pun tidak bisa dijawab secara singkat. Akan tetapi karena masalah ini berkaitan dengan pemikiran teologinya, maka perlu untuk menyampaikannya, sekalipun hanya sekedar sebagai penjajagan awal.

\section{ASPEK-ASPEK PEMBAHARUAN AD-DAHLAWI>}

Masa kehidupan ad-Dahlawiditandai oleh kehidupan sosial politik yang tidak menguntungkan. Dinasti Mogul di India sedang diambang kehancuran. Sepeninggal Aurangzeb pada tahun 1707 M, kelompokkelompok non Muslim mulai mengobarkan api pemberontakan. Maratta di Dacca, Sikh di Punjab, Rajput dan Jat di lembar Jumna. Bahkan para gubernur Muslim pun banyak yang memproklamirkan diri melepaskan dari kekuasaan Mogul, sehingga praktis kekuasaan raja hanya terbatas di daerah Delhi dan sekitarnya. ${ }^{17}$ Pada saat Aurangzeb meninggal tersebut, usia Syah Wali Allah, baru sekitar empat tahun. Setelah itu berturut-turut mengalami dipimpin sembilan orang raja, yaitu Bahadur Syah I, Mu'iz ad-Din Jahandar Syah, Farrukh Siyar, Rafi' ad-Darajat, Rafi' ad-Daulah, Muhammad Syah, 
Ahmad Syah, 'Alamgir II dan Syah 'Alam. Masing-masing raja tersebut ia saksikan sebagai orang-orang yang tidak bisa mengendalikan pemerintahan, bahkan suasana pemberontakan dan kehidupan elite pemerintahan yang senang berfoya-foya menambah lagi kekacauan di pemerintahan yang tidak lagi bisa memikirkan nasib rakyatnya. Suasana tersebut bertambah tragis lagi manakala para ulama hanya memikirkan dirinya sendiri, mereka jumud, kaum sufi terlena hingga mereka cenderung menyia-nyiakan ketentuan agama, akibatnya kaum sufi ini justru keluar dari hakekat tasawuf itu sendiri. ${ }^{18}$

Melihat kenyataan di atas, Syah Wali Allah ad-Dahlawi melancarkan kritik dan pembaruannya yang ditujukan kepada masalah-masalah politik dan keadaan sosial umat Islam. Menurut Prof. Dr. Harun Nasution, ada empat hal yang melatarbelakangi pembaharuan Syah Wali Allah, yang sebenarnya didasarkan analisanya mengenai sebab-sebab kelemahan umat Islam, ${ }^{19}$ yaitu:

1. Adanya perubahan sistem pemerintahan dalam Islam dari sistem kekhalifahan menjadi sistem kerajaan. Hal ini menyebabkan berubahnya sistem demokrasi kepada sistem otokrasi yang cenderung kepada kekuasaan absolut. Pajak ditetapkan dengan caranya sendiri yang dibebankan kepada petani, pedagang dan buruh. Selanjutnya hasil pajak dibuat foya-foya oleh kaum bangsawan yang tidak mempunyai pekerjaan apa-apa. Maka, untuk mengatasi hal-hal negatif di atas Syah Wali Allah berpendapat bahwa sistem pemerintahan seperti yang terdapat pada zaman Khulafa ar-Rasyidin perlu dihidupkan kembali.

2. Adanya perpecahan dikalangan umat Islam, yaitu antara aliranaliran yang ada dalam Islam. Antara golongan Syi'ah dengan golongan Sunni, antara aliran Mu'tazilah dengan Asy'ariyah serta Maturidiyah, antara kaum sufi dengan kaum syari'ah. Pertentangan yang paling tajam adalah antara Syi'ah dengan Sunni. Syi'ah dianggap telah keluar dari ajaran Islam. Pendapat yang demikian ditentang keras oleh Syah Wali Allah, seraya menegaskan bahwa kaum Syi'ah sama halnya Sunni, masih tetap orang Islam. Untuk pertentangan-pertentangan antar mazhab di atas Syah Wali Allah berusaha untuk menciptakan suasana damai antar mazhab yang berbeda tersebut.

3. Masuknya ada istiadat dan ajaran-ajaran bukan Islam kedalam keyakinan umat Islam. Menurut pandangan Syah Wali Allah, umat Islam India banyak dipengaruhi oleh ada istiadat dan ajaran-ajaran 
Hindu. Oleh karena itu keyakinan umat Islam harus dibersihkan dari hal-hal yang asing tersebut. Umat Islam harus dibawa kembali kepada ajaran-ajaran yang sebenarnya. Kembali kepada sumber ajaran pokok yaitu al-Qur'an dan as-Sunnah, bukan kepada bukubuku tafsir, fiqh, ilmu kalam, dan lain sebagainya.

4. Akibat dari tidak kembalinya umat Islam kepada al-Qur'an dan asSunnah, maka kebanyakan mereka bersikap taqlid dan hal inilah yang menjadikan mandegnya umat Islam. Oleh karena itu, Wali Allah sangat menentang taqlid dan menganjurkan ijtihad. Ajaranajaran al-Qur'an dan as-Sunnah harus dikembangkan melalui ijtihad yang disesuaikan dengan perkembangan zaman.

Syah Wali Allah dalam beberapa kitabnya, memang banyak melancarkan kritik terhadap pemerintah/penguasa dan kepada umat Islam yang dianggap telah menyimpang dari ajaran al-Qur'an dan as-Sunnah. Dalam kitabnya Hujjah Allah al-Baligah, ia melontarkan kritiknya bahwa penyebab kehancuran negara pada masa ini (masa Wali Allah) disebabkan pada dua hal, yaitu: pertama, penyalahgunaan Bait al-Mal, baik oleh orang yang mengaku sebagai pejuang, para ulama, zahid, penyair yang biasa menjilat raja dan penguasa. Kedua, oleh adanya pembebasan pajak yang memberatkan para petani, pekerja, kaum buruh sehingga mempersulit kehidupan mereka. ${ }^{20}$ Bahkan dalam kitabnya Izalah al-Khafa', ia mengidentikkan pemerintahan raja-raja Islam, sama dengan pemerintahan raja-raja Majusi. Kalau ada perbedaannya hanyalah karena ucapan syahadat secara lisan dan pelaksanaan shalat semata-mata. ${ }^{21}$

Kepada para ulama, para 'abid dan para penyair, orang-orang Islam umumnya ia banyak melontarkan kritiknya melalui kitabnya al-Tafhimat alIlahiyat. Menurut pendapatnya ulama pada saat itu adalah orang-orang yang dungu, karena mereka hanya menyibukkan kepada ilmu-ilmu pengetahuan Yunani, nahwu, sharaf dan ma'ani. Kepada fuqaha' ia menuduhnya sebagai orang-orang yang berbelit-belit sehingga ayat-ayat al-Qur'an dan Hadis Nabi tertutupi oleh pemikiran mazhab. Kepada para 'abid, ia hantam sebagai orang-orang yang mempersulit orang banyak dan hanya mendakwahkan kebohongan dan kebatilan. Orang-orang sufi dikritiknya sebagai orang yang telah melontarkan ungkapan-ungkapan yang tidak bisa disesuaikan dengan al-Qur'an dan as-Sunnah dan menganggap syari'at tidak mempunyai arti penting bagi kehidupannya. Kepada para penyair, hartawan dan orang-orang awam, ia ingatkan agar jangan sampai menyembah para tiran dan menyembah kuburan-kuburan. Ia ingatkan pula, apabila seseorang datang ke tempat keramat makam seorang wali kemudian meminta supaya cita- 
citanya terkabulkan, maka orang tersebut telah melakukan dosa yang lebih besar dari dosa membunuh dan berzina, orang-orang tersebut sama halnya dengan orang yang menyembah patung dan berhala. ${ }^{22}$

Dengan memperhatikan berbagai aspek pembaharuan ad-Dahlawi>, yang telah disampaikan secara singkat diatas, maka dapat dinilai bahwa usaha pembaharuannya tidak hanya dikhususkan pada aspek ajaran Islam tertentu saja, akan tetapi bersifat menyeluruh, baik aspek politik maupun pemahaman terhadap ajaran-ajaran Islam yang lain. Seruannya adalah agar orang-orang kembali beraqidah dan beramal sesuai dengan al-Qur'an dan as-Sunnah serta mayoritas (jumhur) sahabat dan tabi'in. ${ }^{23}$ Oleh karena itu, tidak salah kalau Abu al-A'la al-Maududi menilainya bahwa ad-Dahlawi adalah seorang mujaddid pada masanya. ${ }^{24}$

Usaha-usaha pembaharuan ad-Dahlawi diatas mengingatkan kita kepada seorang ulama pembaharu yang hidup di sekitar abad ke-8 H, yaitu Ibn Taimiyah (w. 728 H). Menurut Fazlur Rahman, program-program pembaharuan Ibn Taimiyah pada dasarnya berisikan re-statement syari'ah dan mempertahankan nilai-nilai agama. Syari'ah yang dimaksudkan adalah suatu konsep komprehensif yang berisikan kebenaran spiritual Sufi (haqiqa), kebenaran rasional ('aql) dari para filosof dan teolog dan kebenaran hukum. ${ }^{25}$ Barangkali tidak terlalu keliru jika adDahlawidigolongkan pada corak yang demikian. Sehingga ad-Dahlawi dapat disebut sebagai Indian Counterpart of Ibn Taimiyah.

\section{PEMIKIRAN TEOLOGI}

Pada bagian pendahuluan telah ditegaskan bahwa dalam rangka mengungkap pemikiran teologi ad-Dahlawi $>$, penulis akan menggunakan rujukan utama kitab $H\{$ ujjah Alla $>$ h al-Ba $>$ ligah, sekalipun kitab ini bukan kitab teologi, karena isinya menyangkut seluruh aspek kajian Islam, yaitu dari masalah tauhid, ibadah, muamalah dalam artinya yang luas (menyangkut seluruh aspek kehidupan sosial), akhlak, tasawuf sampai kepada metodologi pemahaman sumber-sumber Islam. Perlu ditegaskan bahwa, karena uraian-uraian mengenai masalah teologi dalam kitab tersebut tidak pada satu tempat, meskipun ada bab khusus mengenai al-kalam 'ala at-tauh $\{i>d$, tetapi pada bagian-bagian yang lain juga sering disinggung, maka perlu untuk mensistemasikan dengan metode yang digunakan oleh Prof. Dr. Harun Nasution dalam buku Teologi Islam, yaitu yang meletakkan "cardinal subject matter" sebagai pokok kajian. Metode tersebut dianggap sangat tepat untuk menilai atau mengkaji masalah teologi yang belum 
pernah ditemukan dalam buku-buku lain. Namun demikian, tidak semua materi dapat disampaikan disini karena sedikitnya bahan yang didapatkan.

Sebagai seorang pembaharu yang selalu menyeru untuk kembali kepada al-Qur'an, as-Sunnah dan amalan-amalan para salaf, dalam uraianuraian teologinya pun ad-Dahlawiselalu didasari dengan nas-nas al-Qur'an dan as-Sunnah. Akan tetapi dalam tulisan ini, tidak semua dasar yang digunakan oleh ad-Dahlawidapat diikutsertakan, karena yang penting adalah sejauhmana ad-Dahlawimemberi uraian-uraian mengenai teologi.

Di antara pemikiran-pemikiran ad-Dahlawi mengenai teologi yang dapat dikemukakan disini, adalah:

\section{Tauhid}

Menurut ad-Dahlawi>, tauhid adalah dasar dari segala amal kebaikan bagi manusia. Selanjutnya beliau mengatakan bahwa tauhid itu mempunyai empat tingkatan. Pertama, bahwa yang wajib adanya ( $w a>j i b$ al-wuju $>d$ ) hanyalah Allah semata. Kedua, yang menciptakan langit bumi dan seluruh isinya hanya Allah. Ketiga, yang mengatur dan menguasai langit dan bumi dan segala apa yang ada didalamnya hanya Allah. Keempat, yang berhak disembah hanya Allah semata jua. ${ }^{26}$

Uraian ad-Dahlawi di atas, bukan berarti menempatkan Allah mempunyai kekuasaan mutlak atas manusia, sehingga manusia dalam posisi terpaksa melakukan perbuatan (al-jabr), akan tetapi uraiannya tersebut hanyalah merupakan suatu ungkapan dari seorang pembaharu yang berusaha untuk mengikis segala perbuatan kultus individu, syirik dan segala macam khurafat yang memang menjadi salah satu program yang diperjuangkannya. Oleh karena itu uraiannya tersebut memang tidak jauh berbeda dengan prinsip-prinsip tauhid yang dikembangkan oleh para pembaharu lainnya, seperti Ibn Taimiyah, Muh\}ammad ibn 'Abd alWahha $>$ b, Muh\}ammad 'Abduh dan sebagainya.

\section{Kenabian dan Wahyu}

Ad-Dahlawimenegaskan bahwa kenabian bukan merupakan sesuatu yang dapat diperoleh melalui latihan fisik maupun mental, bukan pula pembawaan sejak lahir, maksudnya kenabian itu bukanlah sesuatu tabiat yang telah dicetak yang memaksa kepada orang yang ditunjuk untuk berbuat sesuai dengan kesuciannya. Tabiat kenabian adalah merupakan derajat yang paling tinggi yang diberikan kepada manusia pada suatu waktu 
saja. ${ }^{27}$ Kehadiran seorang Nabi berkaitan dengan kondisi dunia yang sudah parah dan terjadi kerusakan di mana-mana, sehingga Tuhan mengutus seorang Nabi untuk menyelamatkan manusia dan mengembalikannya kepada kedamaian dan ketertiban. Siapapun orangnya di saat yang demikian, orang yang paling suci, jujur, dan berkemauan keras akan diberi ilham untuk menyeru manusia untuk bangkit agar melakukan kebajikan dan menjauhi kejahatan. Orang-orang yang menerima seruan ini akan selamat dan bagi yang menentangnya akan celaka. Nabi dalam melawan orang-orang yang ingkar tersebut dan memusuhinya akan dibekali dengan mu'jizat. Ia selanjutnya dapat menerima wahyu dari Tuhan dan dapat mengisi hatinya secara lahir maupun batin. Untuk itu ia dapat mengerti kehendak Tuhan yang diturunkan dari langit dalam bentuk ungkapan kata maupun huruf. ${ }^{28}$

Bagi ad-Dahlawial-Qur'an adalah merupakan Kala $>m$ Alla $>h$, jadi bukan makhluk. Memang ada sebagian ilmuwan Muslim yang beranggapan bahwa pendapat ad-Dahlawimengenai al-Qur'an adalah wahyu yang diberikan oleh Allah berupa ma'na, sedangkan kata-katanya berasal dari Nabi Muhammad, seperti yang dikemukakan oleh Sir Sayyid Ahmad Khan yang mendasarkan keterangannya dari kitab at-Tafhimat, ${ }^{29}$ dan Fazlur Rahman yang menggunakan analisisnya melalui kitab Sata'at. ${ }^{30}$ Tetapi dalam kitabnya Syarh\} Tara>jim Abwa $>b \quad\{\{a h\} i>h\}$ al-Bukha>ri>, ia dengan jelas membedakan antara wahyu yang al-matluwwu dan gairu almatluwwi. Yang al-matluwwu adalah al-Qur'an dan ghairu al-matluwwi adalah hadis, artinya kalau al-Qur'an adalah baik berupa makna dan lafaz datang dari Allah, sedangkan kalau al-hadis, maknanya saja yang datang dari Allah sedangkan lafaznya datang dari Nabi sendiri. ${ }^{31}$ Demikian juga keterangannya dalam kitab al-Fawz al-Kabir, dengan tegas ia mengatakan bahwa gaya bahasa dan ketinggian sastra dalam al-Qur'an adalah merupakan aspek pokok kemu'jizatan al-Qur'an. ${ }^{32}$

Keterangan yang agak jelas mengenai wahyu al-Qur'an, dapat ditemukan juga tatkala ad-Dahlawi menguraikan perbedaan antara ilham dengan wahyu. Ia mengatakan bahwa wahyu dengan cara apapun bukanlah ciptaan manusia meskipun Nabi memperoleh pengalaman dalam kehidupannya. Di mana pengetahuan Nabi semuanya bersumber dari wahyu Allah yang diterimanya. ${ }^{33}$ Maksud dari keterangannya itu adalah bahwa ilham bagaimanapun terdapat unsur manusia yang terlibat, yaitu penerima ilham akan menterjemahkan terhadap apa yang diilhamkan kepadanya.

Di dalam uraian-uraian ad-Dahlawi, penulis belum menemukan pembahasan mengenai fungsi akal dan wahyu, sebagaimana banyak dikaji 
dalam perkembangan teologi pada masa awal, yaitu apakah akal dapat mengetahui Tuhan dan mengetahui kewajiban-kewajiban manusia atau tidak. Kedua pokok masalah ini dalam kajian teologi klasik berkembang menjadi empat persoalan teologi, yaitu untuk bagian pertama menjadi persoalan sejauhmana akal dapat mengetahui Tuhan dan kewajiban mengetahui Tuhan, sedangkan bagian kedua menjadi persoalan sejauhmana akal dapat mengetahui baik dan jahat dan kewajiban-kewajiban mengetahui baik dan jahat. Sebagaimana kita ketahui bahwa dengan pembahasan empat persoalan di atas telah melahirkan berbagai ciri khas aliran teologi. ${ }^{34}$ Bagi aliran yang berkeyakinan bahwa akal kuat, mempunyai daya (dewasa), maka akan berpendapat bahwa persoalan tersebut dapat diketahui akal. Akan tetapi bagi aliran yang berkeyakinan akal lemah, tidak mempunyai daya (kecil), akan berpendapat bahwa persoalan tersebut tidak dapat diketahui oleh akal dan demikian harus menggunakan wahyu. Namun demikian, sebagai seorang pembaharu, ad-Dahlawi sangat menekankan penggunaan akal. Ia mengatakan bahwa dengan akalnyalah manusia berbeda dengan makhluk lainnya. Kaitannya dengan akal ini ad-Dahlawi dalam kitabnya Hujjah Allah al-Baligah, ${ }^{35}$ banyak mensitir ayat al-Qur'an maupun al-Hadis, seperti:

$$
\begin{aligned}
& \text { "انّ في ذلك لأيات لقوم يعقلون". الاية } \\
& \text { "لوكنا نسمع اونعقل ما كنا من اصحاب السعيد". الاية } \\
& \text { "اول مـن مـاخلق الله تعـالى العفـل فقــال لـه. اقبـل فاقبـل، وقـال لـه. أديرفـادير، }
\end{aligned}
$$

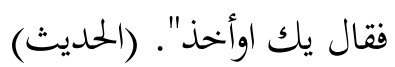

$$
\begin{aligned}
& \text { "دين المرأ عقله ومن لا عقل له لادين له". (الحديث) "افلح من رزق لبألى" }
\end{aligned}
$$

Dengan ungkapan ayat dan hadis di atas, sekalipun ad-Dahlawitidak membahas secara khusus persoalan-persoalan di atas, sudah dapat disimpulkan bahwa ia sangat menekankan pada penggunaan akal dalam berbagai pemahaman terhadap masalah-masalah keagamaan.

\section{Perbuatan Manusia}

Di antara persoalan teologi yang sangat penting, adalah mengenai apakah manusia bebas berbuat atau terpaksa melakukan perbuatan. Dengan persoalan ini pula dapat dipandang sejauhmana seorang teolog menempatkan kedudukan manusia dalam melakukan perbuatan kaitannya dengan 
kekuasaan Tuhan. Bagi yang memandang manusia lemah, tidak mempunyai daya, maka akan berpendapat bahwa manusia tidak mempunyai daya untuk melakukan perbuatan, atau manusia terpaksa melakukan perbuatan (Jabariyah). Bagi yang memandang manusia kuat, mempunyai daya, maka akan berpendapat bahwa manusialah yang menentukan dan melakukan perbuatannya, bukan Tuhan (Qadariyah). Masalah ini pun antara kaum Mu'tazilah, Maturidiah Samarkand, Maturidiah Bukhara, dan kaum Asy'ariyah telah terjadi perbedaan pendapat.

Bagi ad-Dahlawi $>$, setiap manusia itu mempunyai dua kecenderungan, yaitu: pertama, kecenderungan pada kebaikan dan kecenderungan kepada keburukan atau kejahatan. Perbuatan manusia tergantung kepada manusia sendiri untuk memilih atau mengikuti salah satu dari kedua kecenderungan tersebut. Namun demikian, daya manusia untuk melakukan perbuatan adalah atas dorongan Ilahi sesuai dengan keridaannya. Artinya manusia tidak terpaksa melakukan perbuatan, karena hal itu menjadikan Tuhan bersifat tirani, tetapi tidak bisa dikatakan bahwa manusia mempunyai ketetapannya secara mutlak untuk melakukan perbuatan-perbuatan. Manusia berbuat baik dengan pertolongan Tuhan yang telah diterimanya melalui perintah-perintahnya dan manusia berbuat jahat karena ia mengabaikan perintah Tuhan. ${ }^{36}$

Pandangan ad-Dahlawidi atas, sebenarnya ingin membuat sintesa antara aliran Qadariyah (free will) dan Jabariyah (predestination). Akan tetapi sebenarnya tidak jauh berbeda dengan kaum Mu'tazilah, karena sebenarnya manusia menurut pandangan ad-Dahlawi dapat memilih dan menentukan perbuatan baik dan dapat pula menentukan perbuatan buruknya sebagaimana kedua perbuatan tersebut telah ditunjukkan oleh Tuhan setelah datangnya wahyu. Oleh karena itu manusialah yang mempunyai pilihan berbuat baik dan buruk sebagaimana telah diinformasikan oleh Tuhan. Dengan demikian, maka daya adalah manusia itu sendiri dan perbuatan adalah perbuatan manusia sendiri, bukan perbuatan Tuhan.

\section{Iman dan Kufur}

Menurut ad-Dahlawi, Nabi Muhammad saw. oleh Allah untuk seluruh manusia dan supaya agama yang dibawanya mengalahkan semua agama yang ada, oleh karena itu akan melahirkan manusia yang bermacammacam dalam agama. Dalam hal ini dapat dibedakan antara orang-orang yang memeluk agama Islam dengan kuat dengan orang-orang yang tetap memeluk agama selain Islam, dan antara orang-orang yang mendapat petunjuk 
Nabi dengan orang-orang yang tidak memiliki iman dalam hatinya. ${ }^{37}$

Dalam kaitan iman ini ad-Dahlawi berpendapat, bahwa iman dapat dibagi dua macam. Pertama, iman yang berkaitan dengan hukum di dunia seperti selamat dari jiwa dan harta. Artinya iman yang demikian berkaitan dengan masalah-masalah yang dapat dilihat, seperti sabda Rasulullah saw.:

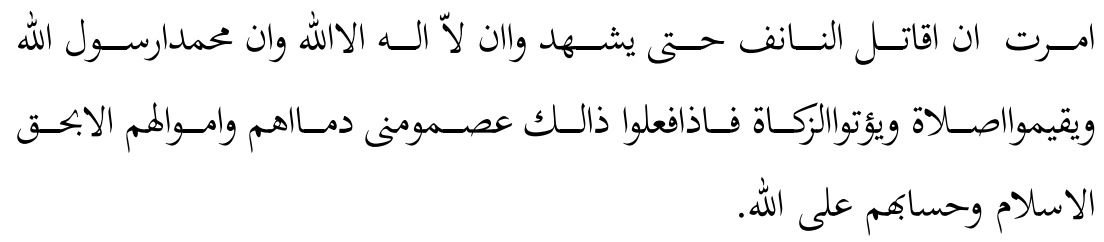

Sedangkan iman yang kedua berkaitan dengan hukum di akhirat, seperti selamat dari siksa neraka, memperoleh kebahagiaan di surga. Iman yang kedua ini harus diperoleh dengan keyakinan yang benar, dengan beramal saleh dan disertai perilaku atau akhlak yang baik. Iman yang demikian ini dapat bertambah (yazid) dan berkurang (yanqus). ${ }^{38}$

Dengan pandangan iman yang demikian, artinya iman itu bukanlah sekedar kepercayaan (tasdiq-al-janan) tetapi harus disertai dengan perbuatan, ad-Dahlawibanyak mengutip hadis-hadis yang berkaitan dengan berkurangnya iman apabila tidak disertai dengan perbuatan tersebut. Untuk mendasari pendapatnya itu ia mengutip sabda Rasulullah saw. yang mengatakan:

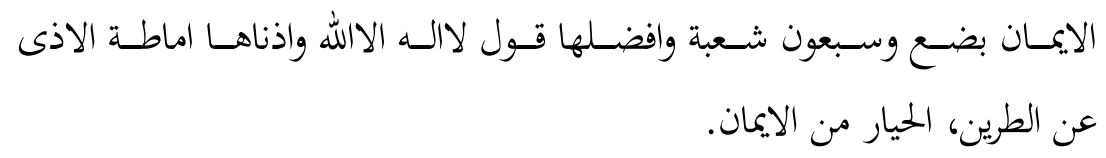

Kemudian ia menyebut beberapa hadis yang berkaitan antara iman dengan perbuatan yang menyebabkan hilangnya atau berkurangnya iman, diantaranya adalah:

$$
\begin{aligned}
& \text { اذزنى العيـــ خـرج منـه الايمـان فكـان فـوق رأسـه كالظلـة فـاذا حسرج مـن ذالـك } \\
& \text { العمل رجع اليه الايمان. }
\end{aligned}
$$

Kebalikan dari iman di atas menurut ad-Dahlawi, untuk yang pertama adalah munafik asli, jika ia tidak memiliki tasdiq dan hanya ingin selamat dari tebasan pedang. Sedangkan untuk macam kedua adalah kufur. Orang munafik dan kufur sama-sama akan disiksa oleh Allah bahkan orang 
munafik akan mendapat siksa di neraka yang paling bawah. Sedangkan orang yang telah memiliki tasdiq tetapi tidak melakukan perbuatan baik (amal saleh), maka ia akan menjadi orang fasiq atau menurut istilah ulama salaf disebut dengan nifaq amal. ${ }^{40}$

Dengan pandangan ad-Dahlawimengenai iman dan kufur, jelas tidak jauh berbeda dengan prinsip ajaran Mu'tazilah mengenai "al-manzilah bain al-manzilatain". Sekalipun ajaran ini berawal dari persoalan dosa besar. Karena dalam ajaran ini, Mu'tazilah mengatakan bahwa orang yang berdosa besar bukan menjadi kafir sebagaimana yang dikatakan oleh kaum Khawarij dan bukan pula tetap mukmin sebagaimana dikatakan oleh kaum Murji'ah, tetapi ia adalah fasik yang menduduki posisi kafir dan posisi mukmin. Demikian juga sesuai dengan ajaran Mu'tazilah yang menekankan pentingnya perbuatan untuk menyertai iman, sebagaimana kita ketahui bahwa kaum Mu'tazilah adalah orang-orang yang sangat taat dan rajin beribadah serta selalu berusaha menghindari dosa karena didorong oleh konsepsinya tentang iman.

\section{Wujud Tuhan}

Di sekitar zaman kehidupan ad-Dahlawi>, banyak dibicarakan mengenai konsepsi wujud Tuhan dalam bidang tasawuf antara pendapat Ima $>\mathrm{m}$ Muh $\}$ yi ad-Di>n ibn al-'Arabi> (1165-1240) yang menggunakan konsep Wahdat al-Wujud (unity of being), dan konsep ulama India, Imam Rabbani Ahmad Sirhindi mengenai wah\}dah asy-syuhu>d (unity of appearance). Wahdah al-wujud mengandung arti bahwa Tuhan pada hakekatnya wujud dalam dunia ini, sedang wah dah $_{\text {asy-syuhu }>d}$ mengandung arti bahwa Tuhan seakan-akan wujud dalam dunia ini.

Dalam kaitan ini ad-Dahlawiberpendapat bahwa, sebenarnya kedua konsep tersebut tidak ada perbedaan. Kedua pendapat itu pada intinya adalah sama, perbedaannya hanya dari segi redaksionalnya saja. Menurutnya, setiap wujud bukanlah semacam atribut atau emanasi dati Tuhan, tetapi terdiri dari sifat-sifat yang non emanative. Bentuk itu hanya bergantung kepada Tuhan. Umpamanya, jika seseorang membuat seekor kuda dari lilin, kita akan mengatakan bahwa bentuk itu adalah kuda. Akan tetapi kalau diamati lebih dalam, sebenarnya kuda itu adalah dalam bentuknya saja, sedangkan wujud yang sebenarnya adalah lilin. ${ }^{41}$

Dengan pendapatnya itu, memang ad-Dahlawiberusaha untuk memadukan antara kedua pendapat di atas, tetapi sekaligus juga merasionalkan dari suatu pemahaman tasawuf yang bersifat mistis. Dengan penda- 
patnya tersebut justru memperkuat peranan akal untuk menangkap wujud Tuhan di dunia, yaitu dengan melihat tanda-tanda kekuasaan Allah yang ada di dunia ini.

\section{Penciptaan Alam}

Ad-Dahlawiberpendapat bahwa, Allah SWT berkaitan dengan wujudnya alam ini memiliki tiga sifat, yaitu al-Ibda', al-Khalqu dan alTadbir. Al-Ibda' adalah mewujudkan sesuatu dari tiada. Ia menggunakan dalil:

$$
\text { سئل رسول الله صلى الله عليه وسلم اوّل هذالامر فقال كان الله لم يكن شبئ قبله. }
$$

Kemudian al-Khalqu adalah menciptakan sesuatu dari bahan materi, seperti menciptakan Adam dari tanah dan sebagainya. Telah ditunjukkan secara naqli maupun aqli, bahwa Allah telah menciptakan apa yang ada di dunia ini berbagai macam jenis dan setiap jenis mempunyai keistimewaannya sendiri. Sedangkan al-Tadbir adalah, Allah mengatur makhluk yang dilahirkan dan menetapkan tujuan-tujuannya yang akan dicapai sesuai dengan hukum dan kemaslahatan yang sesuai dengan kewujudannya. ${ }^{42}$ Berkaitan dengan tadbir ini untuk selanjutnya adalah sejauhmana manusia dapat mengetahui hukum-hukum dan tujuan-tujuan yang telah ditetapkan oleh Allah tersebut, apabila manusia ingin mendapatkan kemaslahatan.

\section{Alam Misal}

Berkait dengan pandangan ad-Dahlawimengenai penciptaan alam. Ia berpendapat bahwa antara dunia fisik dan Pencipta terdapat sesuatu dimana iradah Tuhan dalam bentuk perencanaan pertama-tama dipantulkan, barulah kemudian diwujudkan dalam berbagai bentuk fisik. Semua wujud yang ada di dunia ini pertama dipantulkan dari dunia spirit atau "alam misal", kemudian ditampakkan dalam bentuk material. ${ }^{43}$ Selanjutnya menurut adDahlawi>, antara ruang dan waktu bukan merupakan dua kategori yang terpisah akan tetapi merupakan kategori tunggal. Ruang dan waktu tidak dapat dipisahkan, dan dengan demikian maka penciptaan akan terus berlanjut. $^{44}$

Pendapat-pendapat ad-Dahlawimengenai penciptaan alam, wujud Tuhan, dan alam misal adalah merupakan suatu pendapat yang berkenaan dengan filsafat wujudnya yang dapat disederhanakan bahwa ada wujud yang pasti ada dan ada wujud yang mungkin ada. Yang pasti ada adalah 
Allah (Pencipta) dan mungkin ada adalah selain Allah, yang adanya melalui berbagai sebab.

\section{KESIMPULAN}

Dari uraian-uraian di atas dapat disimpulkan bahwa ad-Dahlawi>, adalah seorang pembaharu akan tetapi ia juga seorang sufi. Kajian-kajiannya kebanyakan didasarkan kepada burhan (demonstrative), wijdan (intuition) dan manqul (traditional knowledge). Namun demikian pandanganpandangan mengenai teologi dapat dikategorikan pada aliran Mu'tazilah, yang lebih banyak menggunakan kekuatan akal.

\section{Catatan Akhir:} 1975), h. 51,

${ }^{1}$ W.C. Smith, Islam in Modern History, (New York: Princeton University Press,

${ }^{2}$ Maryam Jameelah, Islam in Theory and Practice, (New Delhi: Taj Company, 1983), h. 156.

${ }^{3}$ A.H. Siddiqi, Renaisance in Indo-Pakistan: Syah Wali Allah Dahlawi, dalam, A History of Muslim Philosophy, vol. II, M.M. Sharif (ed.), (Weisbaden: Otto Harressowitz, 1966), h. 1577.

${ }^{4}$ G.N. Jalbani, Teaching of Syah Waliyullah of Delhi, (Lahore: Ashraf Press, 1967), h. 4.

${ }^{5}$ Al-Sayyid Sabiq, Kata Pengantar, dalam Syah Wali Allah ad-Dahlawi, al-Inshaf fi Bayan Asbab al-Ikhtilaf, (Kairo: Dar al-Nafais, 1977), h. 10.

${ }^{6}$ Sir Sayyid Ahmad Khan, menyebut nama Syah Wali Allah dengan sebutan Hujjah Allah al-Baligah, dalam Principles of Exegesis, Muslim Self Statement in India and Pakistan, Azis Ahmad and G.E. Van Grouneboum (eds), (Weisbaden: Otto Harressowitz, 1970), h. 27.

${ }^{7}$ Al-Kandahlawi, Awjaz al-Masalik ila Muwatta Malik, juz I, (Beirut: Dar al-Flkr, 1973), h. 74. Baca pula, ad-Dahlawi, Hujjah Allah al-Baligah, (Kairo: Dar al-Turas, t.t.), lampiran terakhri.

${ }^{8}$ An-Namir, Tarikh al-Islam fi al-Hind, (Kairo: Dar al-'Ahd al-Jadid, 1959), h. 413.

${ }^{9}$ Ibid.

${ }^{10}$ M. Mujeeb, The Indian Muslims, (London: George Allen and Unwin Ltd., 1967), h. 277.

${ }^{11}$ Ad-Dahlawi, Hujjah, h. 3.

${ }^{12}$ Harun Nasution, Pembaharuan dalam Islam, Sejarah Pemikiran dan Gerakan, (Jakarta: Bulan Bintang, 1982), h. 20.

${ }^{13}$ An-Namir, Tarikh, h. 414. 
${ }^{14}$ Al-Kandahlawi, Awja $>$ z al-Masa >lik ila Muwatta Ma>lik, (Beirut: Dar al-Fikr, 1973), h. 74.

${ }^{15}$ Ad-Dahlawi, Hujjah., h. 38-48.

${ }^{16}$ S.A.A. Rizvi, Shah Wali Allah and His Time, (Canberra: Ma'rifat Publishing House, 1980), h. 229.

${ }^{17}$ Joseph Schacht and C.E. Bosworth, The Legacy of Islam, (Oxford University Press, 1974), h. 137.

${ }^{18}$ An-Namir, Tarikh, h. 414.

${ }^{19}$ Harun Nasution, Pembaharuan, h. 20-22.

${ }^{20}$ Ad-Dahlawi, Hujjah., h. 45.

${ }^{21}$ Pendapat tersebut dikutip oleh Mas'ud an-Nadawi dalam, Tarikh Da'wah alIslamiyah fi al-Hind, (Dar al-Arabiyah, t.t.), h. 144.

${ }^{22}$ Ibid., h. 148-152.

${ }^{23}$ Ad-Dahlawi, Hujjah, h. 170.

${ }^{24}$ Al-Maududi, A Short History of the Revivalist Movement in Islam, (Lahore: Islamic Publication, 1963), h. 79.

${ }^{25}$ Fazlur Rahman, Islam, (Chicago: The University of Chicago Press, 1979), h. 111.

${ }^{26}$ Ad-Dahlawi, Hujjah, h. 58-59.

${ }^{27}$ Ibid., h. 84.

${ }^{28}$ Ibid., h. 35.

${ }^{29}$ Ahmad Khan, Principles of Exegesis, h. 27.

${ }^{30}$ Fazlur Rahman, Divine Revelation and the Prophet, Hamdard Islamicus, Vol. I, no. 2. Autumn, 1978, h. 67.

${ }^{31}$ Ad-Dahlawi, Syahr Tarajim Abwab Sahih al-Bukhari, (Hyderabad: Da'rah alMa'arif al-Osmania, 1982), h. 5.

${ }^{32}$ Ad-Dahlawi, al-Fawz al-Kabir fi Usul at-Tafsir, (Kairo: al-Muniriyyah, 1346 H), h. 33 .

${ }^{33}$ Ad-Dahlawi, Izalah, h. 162.

34 Aliran-aliran teologi tersebut adalah Mu'tazilah, Maturidiah Samarkand, Maturidiah Bukhara, Asy'ariyah, pada periode akhir muncul diantaranya teologi Muhammad Abduh. Diantara aliran teologi diatas yang paling banyak menggunakan akal adalah Muhammad Abduh, Mu'tazilah, disusul dengan yang agak lemah menggunakan akal adalah Maturidiah Samarkand, Maturidiah Bukhara dan yang paling lemah adalah teologi Asy'ariyah.

${ }^{35}$ Diantaranya pada, ibid., h. 88.

${ }^{36}$ Ad-Dahlawi, Izalah... op.cit., h. 51.

${ }^{37}$ Ad-Dahlawi, Hujjah, h. 162.

${ }^{38}$ Ibid.

${ }^{39}$ Ibid., h. 162-163. 
${ }^{40}$ Ibid., h. 163.

${ }^{41}$ Ibid.

${ }^{42}$ Ibid., h. 11-12.

${ }^{43}$ Ibid.

${ }^{44}$ Ibid.

\section{DAFTAR PUSTAKA}

ad-Dahlawi>, Syah Wali Allah, al-Fawz al-Kabir fi Usul at-Tafsir, (Kairo: al-Muniriyyah, $1346 \mathrm{H}$ ). , Hujjah Allah al-Baligah, (Kairo: Dar al-Turas, tth.). , Al-Ins\} $a>f f i>$ Baya $>n$ Asba>b al-Ikhtila $>f$, (Kairo: Dar alNafais, 1977.) , Izalah al-Khafa, ed. Basgir Ahmad, (Benares: Dairah alHilal, 1979).

Syah $;$ Tarajim Abwa>b $\quad S\} a h\} i>h \quad$ al-Bukha>ri>, (Hyderabad: Da'rah al-Ma'arif al-Osmania, 1982). , Al-Khair al-Kasli>r, ed. Basgir Ahmad, (Benares: Dairah al-Hilal, 1985).

Al-Kandahlawi, Zakaria, Awjaz al-Masalik ila Muwatta Malik, (Beirut: Dar al-Fikr, 1973).

An-Nadawi, Mas'ud, Tari> kh Da'wah al-Islamiyah fi al-Hind, (tp: Dar al-Arabiyah, t.th.).

An-Namir, Tari $>$ kh al-Isla $>m$ fi $>$ al-Hind, (Kairo: Dar al-'Ahd al-Jadid, 1959).

Helepota, A.J. Philosophy of Shah Wali Allah, (Hyderabad: Sind University Publication, t.th.).

Iqbal Muhammad, The Reconstruction of Religious Thought in Islam, (Lahore: Syaikh Muhammad Asyaraf, 1962).

Jalbani, G.N., Teaching of Syah Waliyullah of Delhi, (Lahore: Ashraf Press, 1967).

Jameelah, Maryam, Islam in Theory and Practice, (New Delhi: Taj Company, 1983). 
Khan, Sir Sayyid Ahmad, "Principles of Exegesis", Muslim Self Statement in India and Pakistan, Azis Ahmad and G.E. Van Grouneboum (eds), (Wiesbaden: Otto Harressowitz, 1970).

Maududi, Abu al-A'la, A Short History of the Revivalist Movement in Islam, (Lahore: Islamic Publication, 1963).

Mujeeb, M., The Indian Muslims, (London: George Allen and Unwin Ltd., 1967).

Nasution, Harun, Pembaharuan dalam Islam, Sejarah Pemikiran dan Gerakan, (Jakarta: Bulan Bintang, 1982).

, Teologi Islam, (Jakarta: UI Press, 1986).

, Pembaharuan Abduh dan Teologi Rasional Mu'tazilah, (Jakarta: UI Press, 1987).

Rahman, Fazlur, "Divine Revelation and the Prophet", Hamdard Islamicus, Vol. I, no. 2. Autumn, 1978. , Islam, (Chicago: The University of Chicago Press, 1979).

Rizvi, S.A.A., Shah Wali Allah and His Time, (Canberra: Ma'rifat Publishing House, 1980).

Schacht, Joseph, and C.E. Bosworth, The Legacy of Islam, (Oxford University Press, 1974).

Siddiqi, A.H., Renaisance in Indo-Pakistan: Syah Wali Allah Dahlawi, A History of Muslim Philosophy, vol. II, M.M. Sharif (ed.), (Wiesbaden: Otto Harressowitz, 1966).

Smith, W.C., Islam in Modern History, (New York: Princeton University Press, 1975). 